THURSDAY, OCTOBER 3, I872

\section{BOTANICAL MUSEUMS}

$\mathrm{T}$ $\mathrm{E}$ question of the future relations of the national herbarium at the British Museum to that at Kew is at present engaging the attention of the Royal Commission on Science. The minute of $24^{\text {th }}$ July last shows that it will presently be dealt with by the Treasury. On the motion of Messrs. Bentham and Ball, at the recent meeting of the British Association at Brighton, the Committee of the Biological Section secured an instruction to the Council of the Association to take action in connection with this question in the interests of botanical science; and the question has been submitted to the reaciers of NATURE in an anonymous article on "Botanical Museums," published on the 23 rd March last year.

The authorship of this article was unknown to me until I was summoned to give evidence before the Royal Commission on Science. At the request of the President of the Commission, the proof of Mr. Bentham's evidence was placed before me; I then saw that the article alluded to was incorporated in it, and in the statement with which Mr. Bentham introduced it I read his history of its preparation and publication.

In dealing with this part of Mr. Bentham's evidence, I informed the Commissioners (Q. 7,739-40) that the opinions and arguments stated in it had been, two years before, submitted by Dr. Hooker, through the Board of Works, to the trustees of the British Museum, and had been answered by my predecessor, Mr. Bennett, to the satisfaction, as I then understood, not only of the trustees, but of the authorities at the Board of Works, and that the article on "Botanical Museums" was merely a reproduction of this official paper, without any reference to its answer.

After supplying the date of this official document, my examination, under the guidance of the Commissioner who was then dealing with me, took another direction. On subseguent reflection I therefore felt it necessary to ask leave to present a detailed reply to the Commissioner, which was granted. This reply is printed with the other evidence in the recently printed Blue Book (p. 44).

That the readers of NATURE who have already perused Mr. Bentham's article may have the opportunity of considering my answer, I submit it to them, earnestly desiring that this question now raised should be fully and exhaustively considered, and that no hasty or one-sided judgment should be arrived at ; bcing thoroughly convinced that the action to be taken by the Treasury, whatever it may be, will seriously influence the whole future of the science of botany in England.

I desire to submit to the Commissioners my views:(I.) On the statements contained in Mr. Bentham's paper, and (II.) on the matters naturally flowing out of these statements.

\section{The statements contained in the paper}

I. The views expressed by $\mathrm{Mr}$. Bentham regarding the main purposes of a botanical museum and herbarium, and the requirements of a collection for such a close study of plants as would supply a "sound foundation upon which the science of botany can be usefully established," arise from his estimating the science of botany as limited to that particular department of it to which he has devoted voL. vI. his life, and in which he has done important service. The profound study of plants is, in his view, "their accurate determination and practical classification," and he states that he requires for its prosecution nothing more than an exhaustive herbarium of the fragments of plants supplying the diagnostic characters at present employed for distingtishing genera and species, with a complete library and staff of officers. This is, in my opinion, a very defective estimate of the science of botany, and of the materials required for its advancement.

Robert Brown took a very different view of the profound study of plants, and in the Botanical Department of the British Museum he tried to develope that masterly grasp of the science which is to be found in his. works, by illustrating, as far as possible, the structure of all plants from the lowest to the highest, both existing and extinct. Accordingly, the National Herbarium, large as it is, forms but a part of the botanical collections. The specimens placed in the outer rooms, which exhibit chiefly the form and structure of the stems and roots of plants, are as necessary a part of the purely scientific collection as the dried foliage and flowers in the herbarium. While such specimens "excite the interest," and "gratify the curiosity" (and, what is more important, instruct the minds) "of the general public," these are very far from being their principal, still further from being their only purpose in a botanical museum, as $\mathrm{Mr}$. Bentham appears to imply. The scientific investigator whose notion of systematic botany is somewhat larger than ascertaining the technical name and order of a plant, consults these specimens as he does the herbarium. It is, therefore, a mistake to suppose that they, "when once placed, require no further handling."

The purely scientific collection of the British Museum consists of :-I. The herbarium, comprising $(a)$ the general herbarium, $(b)$ the British herbarium, $(c)$ various separate small and complete herbaria of historical interest. II. The structural series, comprising $(a)$ the fruit collection, (b) the collection of gums, resins, and other natural products, $(c)$ the general collection, exhibiting the form and structure of plants, and consisting of the larger specimens chiefly exhibited to the public; and $(d)$ the microscopical preparations, illustrating the minute structure of recent and fossil plants.

2. The limitation of the science of botany to the plants now existing on the earth is another grave defect. No subject has recently received more attention from biologists than the relation between existing and extinct plants and animals. Every philosophic estimate, or systematic classification of the one kingdom or the other must include the fossil as well as the recent. This is fully acknowledged and acted upon by zoologists, and no better illustration can be adduced than Prof. Huxley's "Introduction to the Classification of Animals" (1869). In botany also, in the standard and only complete Genera Plantarum, by Endlicher, the fossils are ranged in their systematic position with the recent plants. It is true that the Genera Plantarum now in progress, of which $\mathrm{Mr}$. Bentham is one of the authors, ignores all extinct plants. This retrogade step is in entire accordance with the view's expressed by Mr. Bentham in NATURE. A systematic account of the Lycopodiacee which took no notice of the arborescent forms of palæozoic age, or of the Cycadea which ignored the numerous forms and remarkable variations of this order in the secondary rocks, would be obviously very incomplete and unsatisfactory. In forming a collection to supply a sound foundation for the science of botany, it would be as reasonable to exclude the plants of any existing botanical province-say Australia-as to omit those which have existed at any particular period of the earth's history-say that of the Wealden.

3. The distinction which Mr. Bentham draws between a herbarium "for the close study of plants" and one for their "rapid determination without dissection" is most 
undesirable, and, in my opinion, practically impossible. No botanist has so extensive an acquaintance with the vegetable kingdom as to be able to make "a close study," in his necessary work, of every group of plants he may be naming or arranging; he must in many groups make a "rapid determination without dissection." If Mr. Bentham's distinction were in force, and the two herbaria he proposes existed, he would himself, when rapidly naming some of the important collections which have passed through his hands, have often been driven from the great scientific collection to work in his single specimen herbarium with the "general naturalist," " the palæontologist," and " the mere amateur." Every systematic botanist is at first, and more or less all along, a "comparer" of plants. The man who begins as a mere comparer naturally becomes a close student under the influence of the collection he is consulting, and the workers he encounters in that consultation.

4. Mr. Bentham's single specimen herbarium is chiefly intended for the palæontologist, and in addition he proposes to provide him with "separate collections of leaves and fruits, .. so arranged as to enable them to be rapidly glanced over," and these, it is added, "would be most useful." No better testimony to the utter worthlessness of such materials for the purpose proposed can be adduced than the criticisms of Mr. Bentham himself, on the evidence for the existence of the natural order Proteacea in Europe, from leaves found in Tertiary strata. Mr. Bentham was specially fitted to deal critically with the hundred fossil species referred to this order, as he had just made the analysis and detailed descriptions of between five and six hundred Proteacece. The Order is also the best fitted to test the value of the leaf characters on which the fossils had been referred to it, because, as he testifies, it " is one of the most distinct and most clearly defined amongst phanerogams," and is without " a single plant intermediate in structure between that and the nearest allied orders." With regard, then, to the leaves of this order, Mr. Bentham says, "I must admit that there is a certain general facic's in the foliage of this order that enables us in most, but not in all cases, to refer to it with tolerable accuracy -leafy specimens known to have come from a proteaceous country, even without flowers or fruit-but as to detached leaves, I do not know of a single one which, in outline or venation, is exclusively characteristic of the order, or of any one of its genera." I cannot reconcile this declaration by Mr. Bentham to the Fellows of the Linnean Society as their President in May I870, with the statement published by him within a year thereafter, that such a collection of detached leaves not for a limited and exccptionally defined order, but for the whole vegetable kingdom, "would be most useful."

I must further observe that Mr. Bentham has overlooked the fact that a large proportion of fossil plants have been determined from their internal structure, that is. on evidence which no mere herbarium, however extensive, can supply, far less one for rapidly determining plants without dissection, or a collection of detached leaves. The palæontologist requires the most extensive collections possible for his work, and he must be a working zoologist or botanist. All such work done by mere "geologists" and on such data as Mr. Bentham proposes to supply would always deserve strong condemnation.

\section{The matters flowing out of thcse statements}

In considering the matters naturally flowing out of $\mathrm{Mr}$. Bentham's paper, and the views I have now expressed, I venture, firstly, to submit the reasons which make it desirable in my opinion to retain the two herbaria as separate and independent institutions.

I. The two herbaria already exist, and are to a considerable extent parallel collections. Mr. Bentham, whose extensive private herbarium formed the foundation of the public herbarium at Kew, declared, in 1858 , "that a great portion of the additions to the Banksian herbarium since Sir Joseph's death are duplicates of those already at Kew." As the Banksian plants form less than a quarter of those now existing in the British Museum herbarium, the duplicates would be, according to $\mathrm{Mr}$. Bentham, about three-fourths of the whole. Sir William Hooker, also, whose large collections form the great bulk of the Kew herbarium, testificd, in 1858 , that "the Muscum specimens are to a great extent duplicates of those at Kew." And the present Director of Kew Gardens corroborated this statement at that time. In I 860 Sir William Hooker further said, in reference to the transfer of the National Herbarium to Kew as affecting the herbarium there, "To Dr. Hooker and myself it literally and truly can be a matter of no consequence."

2. The two herbaria have been under different management, and to some extent express different results of "the close stidy of plants." The important bearing of this consideration on botanical science in Britain can scarcely be overestimated. One practical illustration may be adduced. The most varied views are entertained by botanists as to the limits of a species, and consequently as to what constitutes a duplicatc. Thus, in the case of the indigenous flowering plants of Britain, $\mathrm{Mr}$. Bentham considers them to form 1,274 spccies; Dr. Hooker, in his recent Flora, makes 1,473 species; Prof. Babington increases the number to $1,64 \delta$ species; while a botanist adopting the views which Jordan and some continental authors have applied to local floras, would make them three or four times more numcrous than even the last estimate. It is quite obvious that these different botanists have each very different notions as to "duplicates," and that a distribution undertaken by Mr. Bentham would certainly result in the loss to the herbarium of plants which Dr. Hooker would consider good species, and the "duplicates" distributed by Mr. Bentham or Dr. Hooker would include numerous plants which would be of the utmost value in M. Jordan's eyes. The two herbaria, existing, as they do, under different directors, to a considerable extent counteract these and other analogous evils.

3. The objects of the two herbaria are fundamentally citierent, and in as far as they fulfil these objects, they are employed for totally different purposes. The National Herbarium at the 13ritish Museum was founded in 1827 for the use of the scientific botanist ; while that at Kew was, as Dr. Hooler says, "originally maintained expressly for the use of the gardens." This was the primary object for which Sir W. J. Hooker accepted the private herbarium of Mr. Bentham in 1855 . Before that year the gardens had been fulfilling thcir proper functions without a scientific herbarium attached to them. The two editions of the "Hortus Kewensis" are the best testimony to the efficiency of the gardens, and to the value of the collections brought together there under the Aitons. No herbarium of any kind, I bclieve, existed at the gardens during their time. The Banksian Herbarium was often and for a long time systematically uscd for naming the Kew plants; and the strictly scientific portion of the "Hortus Kewensis" was the work of Solander, Dryander, and Brown, the successive curators of the Banksian Herbarium. Even Sir W. J. Hooker, the successor of the younger Aiton, who raised the gardens to their present eminence, had no public herbarium from the time of his appointment in $\mathrm{I} S_{4} \mathrm{I}$ to $\mathrm{I} \mathrm{S}_{55}$. It is, therefore, evident that a great scientific herbarium is not a necessity to the efficiency of the gardens at Kew.

It is, however, certain that such a herbarium as Sir W. J. Hooker and Dr. Hookcr desired, that is, one sufficient to enable the officials to name the plants in the gardens, would be a most useful adjunct at Kew, as it would save the great waste of time which would be incurred in consulting a herbarium at a distance. Inasmuch as growing plants are, to the extent that they are developed, perfect, and pernit thorough examination, it is obvious that the 
single specimen herbarium proposed in NATURE would meet all the requirements at Kew, and this could be kept up as suggested by Mr. Bentham from the duplicates not required in the great National Herbarium, all being accurately named before being sent.

4. The practical difficulties in the administration of two separate, and to some extent independent, herbaria would be numerous and serious, and in the course of time a condition of things similar to what at present exists would result. It is needless to speak of a London herbarium, consisting of single specimens of each species, because such a herbarium, if practicable, would, as I have already shown, be utterly worthless for the purposes to which it is proposed to be applied. If the London herbarium were to contain only specimens sent by the keeper of a herbarium, whose notion of the science of botany was confined to the "accurate determination and practical classification " of herbarium specimens, it is obvious that the palæontologist would not find there the materials for prosecuting his work. If, on the other hand, the London herbarium were constituted to be of real use to the palæontologist, the keeper must have the power of acquiring as opportunity offered the suitable materials, and he would necessarily secure collections which a future agitator might demand to be transferred to Kew, with as pertinent reasons as those $\mathrm{Mr}$. Bentham now employs.

5. Jt is not an unimportant consideration that the continued separate existence of these two great herbaria is a great security against their destruction by fire.

6. The expense of the two herbaria is very small. I am unacquainted with the amount granted for Kew herbarium, but it cannot greatly differ from that required by the $\mathrm{Na}$ tional Herbarium, which amounted for the financial year lately completed to $1,767 \mathrm{l}$. I know of no way in which the country can at once advance the interests of science and encourage its students, at a smaller cost and with more important results than by maintaining in their full efficiency the two botanical collections at present existing.

But, secondly, it must be admitted that the formation of a single great national botanical establishment, comprising the two public herbaria now existing within a comparatively small distance from each other, is a very attractive scheme, and should the Commissioners think that its realisation is desirable, I submit the following considerations as in my opinion essential :-

I. It must form part of the National Museum of Natural History. Such a museum, as far as it is an exhibition of biological science, will consist of animals and plants, both existing and extinct. It is absolutely necessary in the study of geology that the plant remains should not be separated from the animal remains; and further, it is as necessary for the satisfactory interpretation of the fossil plants, as well as for forming a true estimate of the vegetable kingdom that the recent plants should not be separated from the fossil. The separation of any one department would be a serious injury to all.

2. It must represent the whole science of botany, and not consist of only dried foliage and flowers, which constitute a herbarium properly so called; and consequently it must be formed on the principle adopted by Robert Brown, and exhibited in the Botanical Department of the British Museum, and not on the imperfect plan advocated by Mr. Bentham.

3. It must be placed in the position in which it will be most serviceable to the public and most accessible to botanists, and that place is beyond all question London. The statistics which I submitted on the occasion of my former examination establish this, by showing the extent to which the botanical collections at the British Museum are made use of. Further, it is universally acknowledged that a herbarium for scientific use must exist in London. The long experience of Mr. Brown and $\mathrm{Mr}$. Bennett in the National Herbarium made them entertain and express very decided views as to this necessity. My shorter experience has been long enough to convince me that its removal to Kew would be practically placing it out of the reach of the busy men who frequently use it to the advantage of science. Of course the working botanist who devotes himself exclusively to the science would follow the collections wherever they went; but the active professional man, and the man of business, who devote their spare hours to botany, would be deprived of the assistance necessary to their work which they now obtain at the British Museum. That such men do a large proportion of the scientific work of the country may be shown in many ways, as for instance, by the fact that out of the nineteen botanical memoirs contained in the last two volumes of the Linnean Transactions, four are produced by professional botanists, and fifteen by others.

The late Prof. Henfrey, as representing the botanical teachers of London, Sir Charles Lyell, for the palrontologists, and Dr. Falconer, Mr. Bentham, and Dr. Hooker, have recorded it as their decided opinion that the interests of science require that a public herbarium should exist in London. Such a herbarium, even if used only by palæontologists, must be, as I have shown, as extensive as possible ; otherwise, it will tend to mislead, like all other imperfect sources of information.

1 would further add in favour of London being the proper site for the national botanical collections, that important collections of plants, both recent and fossil, accessible to students, but not to the general public, now exist and must still remain in London. These are: (I) the Linnean herbarium, containing the plants described by Linnæus; (2) the great Wallichian herbarium; (3) the Smithian herbarium of British plants; all belonging to the Linnean Society; (4) the collection of fossil plants belonging to the Gcological Society ; and (5) the extensive public collection of fossil plants in the Museum of Practical Geology. The removal of the National Botanical Collection from London would so separate them from these collections as seriously to injure their value to scientific investigators.

4. The accommodation provided for the Botanical Department in the New Muscum of Natural History, the plans of which have been accepted by the trustees of the British Museum, will be in every way superior to any that exist in the world, and will be amply sufficient to accommodate the proposed single national herbarium, as well as fully to display the structura!, histological, and palæontological departments of the sciencc. All the requisites specified by Mr. Bentham for the close study of plants, excepting the connection with a garden, exist to a greater or less degree at the British Museum, and some of them in a greater degree than at Kew. That living plants are a requisite adjunct to a herbarium is in opposition to the testimony of Mr. Brown and Dr. Falconer, to the effect that there is no necessary connection between a herbarium and a garden ; and is opposed moreover to the testimony of Mr. Bentham himself, as well as to his declaration th it his extensive systematic labours have all been based on herbarium specimens, although they have been carried on in close proximity to the finest scienticic garden in existence.

In the event then of its being resolved to maintain only one great national botanical collection, I would submit that it should not be cut off from the allied biological collections, but be placed with them in the same building in London. And that for this end the collections presented by Mr. Bentham to the public, and all that have been added to them by purchase or presentation, be removed to London and incorporated with the national herbarium; and further, that the extensive botanical library formed at the national expense at Kew be made, with the Banksian library, the foundation of that national natural history library which will be required for the National Museum of Natural History.

It is necessary, in dealing with Mr. Bentham's printed 
and publicly expressed views on this matter, to bear in mind that he cannot be considered an unprejudiced witness. I have frequently referred to his relations to the herbarium attached to the Royal Gardens at Kew. He has thus stated the reasons by which he was influenced in presenting his herbarium and library to the public in I 855 :- "I thought that at that "time there was no herbarium and library in London sufficiently open for the use of botanists, and I presented them on condition that they should form the nucleus of a national herbarium and botanical library, to be kept at the expense of Government, and open to the free use of botanists." I can assert in opposition to Mr. Bentham's belief-and a similar opinion bas been, I understand, recently expressed-that at that time the National Herbarium and the national library, as far as it is an adjunct to the herbarium, were fully and freely accessible to botanists, and were largely used by botanists; and this I am able to maintain from the contemporary records of this department, as well as from the testimony of botanists who were then in the habit of consulting the collections. Under the influence of this erroneous supposition, Mr. Bentham made his own herbarium a national institution, and a rival to the Banksian herbarium, and under the influence of this same spirit of rivalry, he now believes that there exists "a state of continual competition" between the two herbaria. I am sure that Dr. Hooker and the authorities at Kew will as strongly repudiate this statement as I do now, if it is meant to imply a competition in any way to the injury of science or the public. It is only in keeping with the motives which actuated him at the first that $\mathrm{Mr}$. Bentham now agitates for the incorporation of the Banksian herbarium with that of which his own forms the nucleus. WILliaM CARRUTHERS

\section{FRESENIUS'S QUALITATIVE ANALYSIS}

Qualitative Chemical Analysis. By Dr. C. Remigius Fresenius. Eighth edition. Translated from the I 3 th German edition, by A. Vacher. (London: J. and A. Churchill.)

7 HE present edition of Fresenius is one which will 1 be looked at by chemists with interest. In the last so-called edition of Fresenius's Chemical Analysis, published in 1869 , the text had been so altered and curtailed that the volume could scarcely be recognised as Fresenius of old, it having been reduced to about one half of its original size. It appears, however, that this condensation did not coincide with the author's views, and in this edition we have simply a translation of the original text. The editor in his preface confesses that he then, in the last edition, took too broad a view of his duty. It certainly seemed strange that a work which had passed through twelve German editions with a gradual and steady enlargement, could be condensed to about one-half without losing a considerable amount of its clearness and usefulness. We confess that we heard with pleasure of the appearance of the eighth English edition of this work, but, unfortunately, our pleasant anticipation has been to some extent marred.

f. In criticising this book, it will be necessary to consider it from two points of view ; in the first place, to consider the work of the translator; and in the second, the author's responsibilities, and the book itself. To commence with the translator's work : it appears, on the whole, to be very well executed, although by far the greater part of the book is identical with the sixth edition, published in I 864 , and edited by J. Lloyd Bullock; in fact, at first sight, there does not appear to be very much difference between the two editions; but on a closer acquaintance with the present edition, there is found a considerable amount of new matter, and some little alteration in the old. As is almost certain in a book of the size, we have found some sentences which would have been better for a little more attention ; to quote one instance, p. $5 \mathrm{I}$, "Solution of ammonia, although formed by conducting ammoniacal gas $\left(\mathrm{N} \mathrm{H}_{3}\right)$ into water, and letting that gas escape on exposure to the air, and much quicker when heated, may also be regarded as a solution of oxide of ammonium $\left(\mathrm{N} \mathrm{H}_{4} \mathrm{O}\right)$ in water, the first acceding equivalent of water $(\mathrm{H} \mathrm{O})$ being assumed to form $\mathrm{N} \mathrm{H}_{4} \mathrm{O}$ with $\mathrm{N} \mathrm{H}_{3}$." This sentence cannot certainly claim precision and clearness as its chief characteristics, and we have much doubt whether a young student would understand its meaning. Taking the translation, however, as a whole, it is clear and well expressed.

It will be seen from the above quotation that there are some points about this edition which will not recommend themselves to the generality of English teachers ; we refer of course to the nomenclature and notation, which have not been altered since the edition of 1864 . Of course Mr. Vacher is not responsiole for this ; if Dr. Fresenius said the work was to be literally translated, there was no help for it, the old notation must be used, but still we must consider that it is a great mistake. Generally speaking, at the present day for a book to be published in the old notation is sufficient to limit its use to a very small number of students. It certainly seems a great pity that this, which until lately has been looked up to as the best and most reliable text-book on qualitative analysis, should not have progressed side by side with modern chemistry; for English chemists, almost without exception, have adopted the new system of atomic weights, and the new and more systematic nomenclature now in use. The adoption of the old notation in the present volume will add a considerable amount of trouble to the teacher's work, and in many cases may probably lead to the adoption of another text-book. Looking at the very general, in fact almost universal, use of the new notation both in England and on the Continent, it certainly appears that this book is about five years behind the times. On the other hand, the present edition will, perhaps, on this account prove more useful to our manufacturing chemists, who seem very loth to adopt the new notation.

Although we do not feel satisfied, and, in fact, are disappointed, with the book in this respect, we cannot help feeling pleased with the substance matter itself. As might be expected from the numerous editions of his manual which the author has already published, he continues to keep the information contained in the work quite up to the progress of the science. Many parts of the work show alterations, though the very fact of the accuracy of the author's work precludes any very great change. It is in the parts on the rare metals, and on the alkaloids, that there appears to be the greatest amount of new matter. Thus the sections on berylla, thoria, zirconia, tellurium, vanadium, iridium, and didymium, show a considerable increase in our knowledge of these substances; whilst indium, which is not to be found in the edition of 1864 , has here received a very good notice. Again, in the edition of 1864, only one 